\title{
The Effect of the SEC's Accelerated Filing Deadline on Earnings Timeliness
}

\author{
Amy E. $\mathrm{Ji}^{1}$ \\ ${ }^{1}$ Haub School of Business, Saint Joseph's University, Philadelphia, PA, USA \\ Correspondence: Amy E. Ji, Haub School of Business, Saint Joseph's University, 5600 City Avenue, \\ Philadelphia, PA 19131, USA. Tel: 1-610-660-1653. E-mail: aji@sju.edu
}

Received: September 1, 2015

Accepted: October 12, $2015 \quad$ Online Published: November 25, 2015

doi:10.5539/ijef.v7n12p59

URL: http://dx.doi.org/10.5539/ijef.v7n12p59

\begin{abstract}
I examine whether the accelerated 10-K filing deadline affects earnings timeliness. The SEC's acceleration of the filing deadline of Form 10-K took effect in 2003. In proposing a new rule, the SEC asserted that the usefulness of the $10-\mathrm{K}$ would increase because of the improved timeliness of the report. On the other hand, opponents claimed that the quality and accuracy of the report could be impaired. I compare timeliness of pre-acceleration period to that of post-acceleration period. Overall, my findings provide little support for the SEC's claim that the accelerated deadline would improve timeliness of periodic reports.
\end{abstract}

Keywords: earnings timeliness, SEC filings, earnings announcement lag

\section{Introduction}

This paper examines the impact of the acceleration of periodic report filing dates on earnings timeliness. The SEC's acceleration of the filing deadline of Form $10-\mathrm{K}$ took effect in 2003. In proposing a new rule, the SEC asserted that the timeliness and usefulness of the 10-K would improve because of the accelerated filing deadline of the report. On the other hand, opponents claimed that the quality and accuracy of the report could be impaired.

The main objective of this study is to examine whether there is any effect of the accelerated 10-K filing deadline on earnings timeliness defined as the speed at which earnings information is reflected in stock prices. To measure the speed of incorporation of earnings information into stock prices, this paper employs a timeliness measure used in Alford, Jones, Leftwich, and Zmijewski (1993) and Butler, Fraft, and Weiss (2007). The measure examines the speed at which monthly return on hedge portfolios formed based on perfect foreknowledge of annual earnings changes is earned over the three-month period following fiscal year-end. I measure timeliness separately for pre-acceleration period and post-acceleration period so that I can provide evidence regarding the effect of the accelerated deadline.

My results suggest that earnings timeliness did not improve for accelerators during post-acceleration period compared to pre-acceleration period. Although firms filed their $10-\mathrm{K}$ sooner to meet the new reporting requirement, it took longer for them to release their earnings announcement, which can be unintended outcome of the accelerated deadline. Overall, my findings provide little support for the SEC's claim that the accelerated deadline would improve timeliness or relevance of periodic reports.

The study contributes to the existing literature in several ways. First, the evidence extends studies that examine the effect of the SEC's accelerated filing deadline. No significant analysis has been conducted on the effect of the new filing rule, particularly none in the case of potential effects on earnings timeliness. My findings provide little support for the SEC's claim that the accelerated deadline would improve timeliness of periodic reports. By contributing to the ongoing debate over accelerating deadlines for periodic reports, the study has an implication for a number of diverse organizations, including the SEC, audit firms, and firms who are subject to the new rule. Second, by showing capital market implications of the timing of SEC periodic reports, the study contributes to the literature that studies the link between regulated filings and capital market outcomes. Lastly, the study contributes to a more broad literature studying timeliness of accounting information.

The rest of the paper is organized as follows. In Sections 2 and 3, I review prior research and develop a hypothesis. In Section 4, I discuss research design. Section 5 shows sample selection, Section 6 reports results, and Section 7 presents conclusion. 


\section{Background}

\subsection{SEC Filing Requirements}

The Securities and Exchange Commission (SEC) currently requires firms that meet reporting requirement to file periodic reports such as Form 10-K and Form 10-Q on an annual and quarterly basis, respectively. In addition, firms must make major events publicly available by filing Form 8-K.

In 2002, the SEC implemented a new rule to accelerate the filing dates of periodic reports in an attempt to speed up the reporting process, responding to provisions in the Sarbanes-Oxley Act of 2002 (Note 1). The filing deadline for Form 10-K is changed from 90 days to 75 days for fiscal years ending after December 15, 2003. Further, it is changed to 60 days for fiscal years ending after December 15, 2004. However, the implementation of 60-day deadline was delayed until December 15, 2005. In addition, starting the fiscal year on or after December 15, 2003, Form 10-Q should be filed within 40 days of quarter end rather than original deadline of 45 days.

The new rule applies to an "accelerated filer", a domestic reporting company that meets all of the following four requirements as of December 15, 2002: (1) a firm has a public equity float of at least $\$ 75$ million, (2) the firm has met the reporting requirement for at least 12 calendar months, (3) the firm has previously filed one $10-\mathrm{K}$, and (4) the firm is not eligible to file 10-QSB and 10-KSB.

In 2005, the SEC implemented the final rule, modifying its original 2002 proposal (Note 2). The main modification is to create a new category of "large accelerated filer" defined as a domestic reporting company that has a public float of at least $\$ 700$ million and meets all other requirements previously suggested in the 2002 regulation. As a result, the category of accelerated filer includes "large accelerated filer" and "accelerated filer". The category of "accelerated filer" includes firms that have a public float of at least $\$ 75$ million, but less than $\$ 700$ million. The large accelerated filer is subject to 60 day deadline for Form 10-K after December 15, 2006. All other accelerated filers are not subject to 60 day deadline, meaning 75 day deadline is permanent for them. For Form 10-Q, both types of accelerated filer are subject to the 40 day deadline. The current $10-\mathrm{K}$ deadlines for accelerated filers are summarized in Table 1.

Table 1. Revised 10-K deadlines for accelerated filers

\begin{tabular}{lll}
\hline Category of filer & Definition & Revised deadlines for filing Form 10-K \\
\hline Large accelerated filer & Firms with a public float of $\$ 700$ million or more & 75 days for fiscal years ending after \\
& & $\begin{array}{l}\text { December 15, 2003 } \\
60 \text { days for fiscal years ending on or after } \\
\end{array}$ \\
Accelerated filer & Firms that have at least $\$ 75$ million but less than $\$ 700$ & 75 days \\
& million in public float & 90 days \\
Non-accelerated filer & Firms with a public float of less than $\$ 75$ million & \\
\hline
\end{tabular}

The major benefit that the SEC intends to produce by accelerating the filing deadline is to make periodic reports more timely so that they can be more useful to investors. The SEC claims that the legislation would improve the timeliness or relevance of periodic reports. It also believes that capital markets will be more efficient because market participants can make more informed decisions about valuation and pricing more swiftly. The accelerated delivery of valuable information contained in periodic reports will help the market operate more efficiently. In fact, timeliness of financial reporting is one of the two components of relevance required to make accounting information useful for decision makers as suggested by the FASB (Note 3). Furthermore, FASB/IASB conceptual framework for financial accounting and reporting (FASB, 2010) defines timeliness as "having information available to decision makers in time to be capable of influencing their decisions." The disclosure of information should be as timely as possible so that it does not lose its capacity to influence decision-making activities (FASB, 1980).

A possible drawback of the accelerated deadlines is that firms might have to incur higher costs in order to comply with the new rules. For example, firms might need to hire additional staff or upgrade their accounting systems in order to prepare reports in a shorter time frame. Audit fees may increase as well.

Another concern is about the quality and accuracy of reports. Through hastening the report preparation process, firms may produce less precise reports. If the precision of reporting is impaired due to the shortened deadlines, 
capital markets will be less efficient. Furthermore, external auditors, management, board of directors and audit committees would have less time to review and scrutinize reports before they are filed with the SEC. Additionally, because of the reduction in time to prepare and review the reports, the disclosure can be reduced.

\section{Literature Review and Hypotheses Development}

Three strands of research are related to this study. The first strand of research examines the impact of the SEC's decision to shorten the filing deadlines. While my study focuses on the impact on earnings timeliness, other studies examine the effect on firms' ability to file their $10-\mathrm{K}$ on time, earnings quality, or the usefulness of 10-K. The second strand of research provides research methodology that this paper employs. Using hedge portfolio of perfect earnings foresight, the studies examine timeliness of accounting earnings in different countries or the effect of reporting frequency on timeliness. The last strand of research offers background information on timeliness measured by alternative methodologies.

\subsection{Effect of the New Rule}

The impact of the new filing deadlines has been examined in a limited number of studies. Bryant-Kutcher, Peng, and Zvinakis (2007) examine whether the acceleration rule had any effect on firms' ability to file their 10-K on time. By comparing 103 late-filing firms to a sample of 82 timely-filing firms, they conclude that the accelerated deadline did not cause firms to file late. However, they find that firms with a weak system of internal controls had difficulty in meeting 75 day while meeting the deadline was not a difficult task for firms with a good system of internal controls. In addition, they find that main determinants of firms' late filing behavior are audit completion time and firm size.

Krishnan and Yang (2009) document recent trends in 10-K filing lag, audit report lag, and earnings announcement lag in an attempt to examine whether accelerated filing requirements affected these three lags. They document that about $75 \%$ of potential accelerated filers filed their $10-\mathrm{Ks} 75$ or more days after the fiscal-year end in 2001 and 2002, suggesting that most of potential accelerated filers would require a reduction in their $10-\mathrm{K}$ filing lag to meet the new filing requirement in 2003 . Not surprisingly, they document that $10-\mathrm{K}$ filing lag of accelerated filers decreased during their sample period of 2001-2006. However, they suggest small accelerated filers compared to large accelerated filers may have had more difficulty in adjusting to the new accelerated deadline.

Furthermore, they show both audit report lag (the number of days between the fiscal year-end and the audit report date) and earnings announcement lag (the number of days between the fiscal year-end and the earnings announcement date) increased over the period of 2001-2006. They also examine financial reporting quality for their sample period, using two measures of reporting quality (absolute discretionary accruals and quality of accruals). The study concludes that the accelerated filing rule did not lead to lower reporting quality, providing no support for the concern that the legislation may impair reporting quality.

Impink, Lubberink, and Praag (2012) investigate the effect of the acceleration rule on 10-K filing delays. By testing whether the accelerated filing deadlines affect firms' ability to file on time, they find that shortened filing deadlines for firms that are subject to the acceleration rule are not related to changes in the incidence of late filing. They find no evidence that the tightened deadlines are related to an overall increased occurrence of late filing.

Doyle and Magilke (2013) investigate a change in the usefulness of Form 10-K following the new rule. They find smaller accelerators (firms with a public float of more than $\$ 75$ million and less than $\$ 700$ million) face a significant decrease in market reaction around the 10-K filing dates as they accelerate the deadline from 90 days to 75 days. On the other hand, larger accelerators (firms with a public float of more than $\$ 700$ million) do not experience any change in the market reaction as they move from 90 days to 75 days. However, as larger accelerators further shorten the deadline to 60 days, they experience a significant increase in the market reaction. Accordingly, they conclude that, at least for larger accelerators, the acceleration of filing deadlines has resulted in the increase in the overall usefulness of $10-\mathrm{K}$.

Bryant-Kutcher, Peng, and Weber (2013) examine the effects of accelerating 10-K filing deadlines on the quality of accounting information. They document that firms that are required to file more quickly have higher probability of issuing financial statement that are later restated, compared to firms that are not affected by the new acceleration rule. This effect is more pronounced when auditors face significant time pressure during the audit busy season. They document the reduced reliability of the financial reports, which is the possible cost of forcing firms to prepare accounting reports more quickly.

Lambert, Brazel, and Jones (2014) examine potential effects of the accelerated filing deadline by investigating 
whether changes in audit delay are associated with changes in earnings quality, stating that the legislation will lead to a reduction in audit delay or the number of days from fiscal year-end to the date of auditor's report. They reason that a decrease in audit delay will lead to a reduction in audit quality and, in turn, a reduction in earnings quality. They find that reduction in audit delay is associated with the decrease in earnings quality, which is proxied by discretionary accruals. In addition, they document that the association between audit delay and earnings quality does not appear to differ by filer size. In conclusion, they support auditors and preparers who claim that the acceleration has the capacity to reduce quality of financial statements and that imposing the legislation on non-accelerators may bring harmful effects.

\subsection{Earnings Timeliness Measured by Perfect Foresight Hedge Portfolio}

Alford, Jones, Leftwich, and Zmijewski (1993) compare timeliness of accounting earnings in seventeen countries using the United States as a benchmark for the purpose of investigating whether differences in capital markets-accounting standards, disclosure practices, and corporate governance-result in differences in informativeness of accounting earnings. They document the significant differences in the timeliness and information content of accounting earnings among different countries. Their results reveal that annual accounting earnings from Australia, France, the Netherlands, and the United Kingdom are more timely than U.S. accounting earnings. On the other hand, annual accounting earnings from Denmark, Germany, Italy, Singapore, and Sweden are less timely or less value-relevant than U.S. accounting earnings.

DeFond, Hung, and Trezevant (2007) examine differences in the information content of annual earnings announcements among 26 countries. To investigate an association between investor protection and timeliness of earnings information, they follow the approach in Alford et al. (1993). They reveal that earnings information is more quickly reflected in share price in countries with stronger investor protection institutions.

Butler, Kraft, and Weiss (2007) provide evidence regarding whether reporting frequency affects how quickly accounting information is impounded into security prices. They find no difference in timeliness between firms that report quarterly and firms that report semiannually. However, unlike firms mandated to change their reporting frequency from semiannual to quarterly, firms that voluntarily changed their reporting frequency showed improvement in timeliness. Therefore, the study concludes that regulation mandating more frequent reporting is not effective in improving timeliness.

Cuijpers and Peek(2010) investigate whether the choice of reporting frequency affected the precision of investors' information in their sample countries (Denmark, the Netherlands, and the UK) during the period of 2002-2007. Their operational measure of the precision of investors' information is stock price informativeness, which they define as the speed with which stock prices anticipate annual accounting earnings. Following the approach of Alford et al. (1993) and Butler et al. (2007), they use timeliness of accounting earnings to measure stock price informativeness. They conclude that whether a firm chooses to use quarterly reporting or semiannual reporting does not affect the average precision of investors' information.

\subsection{Background on Timeliness}

Givoly and Palmon (1982) find that firms announcing their annual earnings early relative to expectations experience larger market reaction in absolute value than those announcing late. Their classification of early and late announcers is based on the difference between actual announcement date and expected announcement date.

Chambers and Penman (1984) provide evidence that firm size (measured by market value) is inversely associated with earnings announcement lag. In addition, the study suggests that small firms experience larger market reaction in absolute value when they issue earnings reports compared to large firms. Atiase, Bamber, and Tse (1989) find an inverse relationship between reporting delay (i.e. period from fiscal-year end to the annual earnings announcement date) and security price reaction, after controlling for firm size.

Alford, Jones, and Zmijewski (1994) find that firms with extreme (very favorable or unfavorable) economic events are more likely to delay their $10-\mathrm{K}$. Sengupta (2004) finds that firms release their earnings announcements earlier when they face greater demand for information from investors and greater litigation costs. Furthermore, firms with greater block ownership and more complex operation tend to release their announcements later.

\subsection{Hypotheses Development}

This paper examines some of the possible consequences of the new filing requirement. In particular, it focuses on the effect of the rule on timeliness of annual earnings. Doyle and Magilke (2010) document a general description of $10-\mathrm{K}$ filing trend. As expected, filingdays defined as the number of days from fiscal year end to the $10-\mathrm{K}$ filing date has an overall downward trend. Especially, in 2003 when firms were subject to the 75 
deadline, there was a large drop in median filingdays to 75 days from 86 days in 2002 while filingdays were 88 and 86 in 2000 and 2001, respectively. Such a noticeable decrease in filingdays implies that most of the firms had to accelerate their 10-K filings in order to meet the new requirement.

Krishnan and Yang (2009) also document recent trends in $10-\mathrm{K}$ filing. They document that about $75 \%$ of potential accelerated filers filed their 10-Ks 75 or more days after the fiscal-year end in 2001 and 2002, suggesting that most of potential accelerated filers would require a reduction in their 10-K filing lag to meet the new filing requirement in 2003. Therefore, it is possible that the new rule improved earnings timeliness.

On the other hand, Smith (2007) observes an increase in the number of days between fiscal year-end and earnings announcement date in recent years, a trend that can reduce earnings timeliness. As an unintended consequence of the accelerated $10-\mathrm{K}$ deadline, it is possible that earnings announcement date is affected. Most firms release earnings announcement with preliminary earnings figures prior to filing mandatory disclosures with the SEC. Li and Ramesh (2009) reveal that 16 percent of annual SEC reports were filed on the same day when earnings announcements were issued from 1996 to 2006. The relative timing difference in fourth quarter earnings announcement date and 10-K date can affect the respective informativeness of the two disclosures (Li \& Ramesh, 2009; Doyle \& Magilke, 2010). Even if 10-Ks are filed sooner, it is possible earnings timeliness does not improve if it takes longer for firms to issue their earnings announcement.

In 2005, the SEC revised its filing rule, granting "accelerated filers" (firms with a public float of less than $\$ 700$ million) an exemption from a requirement to reduce their 10-K filing date to 60 day deadline. In granting such an exemption, the SEC reasoned that the impact of the acceleration might differ by filer size. The SEC stated that smaller firms seem to have fewer financial resources as well as less well developed infrastructure to meet the 60-day deadline (Note 4). Furthermore, much opposition to the legislation came from small firms rather than large firms. However, "large accelerated filer" (firms that have a public float of at least $\$ 75$ million, but less than $\$ 700$ million) are subject to 60 day deadline for Form 10-K after December 15, 2006. Thus, motivated by the SEC's different category of accelerated filers, I examine the effect of the legislation on earnings timeliness separately for "accelerators" and "large accelerators". Thus, my null hypotheses are as follows:

Hypothesis 1: The SEC's acceleration of filing deadline has no effect on earnings timeliness of "accelerators".

Hypothesis 2: The SEC's acceleration of filing deadline has no effect on earnings timeliness of "large accelerators".

\section{Research Design}

To measure earnings timeliness, this paper employs a timeliness metric used in Alford et al. (1993) and Butler et al. (2007). First, hedge portfolios are constructed based on perfect foresight of annual earnings information for pre-acceleration period and post-acceleration period, separately. Hedge portfolio is formed with long position in firms in top $27 \%$ of scaled earnings changes and short position in firms in bottom $27 \%$. The $27 \%$ cutoff is used because it maximizes test power (Lys \& Sabino, 1992; Alford et al., 1993). Scaled earnings change is computed as (EPSt - EPSt-1)/Pt-1, where EPSt is earnings per share before extraordinary items for year $\mathrm{t}$ and $\mathrm{Pt}-1$ is lagged price.

To test Hypothesis 1, two hedge portfolios are constructed from small accelerators: one for pre-acceleration period (1999-2002) and the other for post-acceleration period (2003-2008). Likewise, to test Hypothesis 2, three hedge portfolios are constructed from large accelerators for the periods of 1999-2002, 2003-2005, and 2006-2008. (Recall that, for large accelerators, the filing deadline was further reduced to 60-day in 2006).

Second, I analyze how fast hedge portfolio returns are earned over a 3-month window following a fiscal-year end to test for timeliness. The cumulative portfolio return at the end of each month of a three-month period following a fiscal year-end is calculated. Monthly hedge portfolio buy-and-hold returns are cumulated during a three-month period after the fiscal-year end. Although prior studies use the cumulative portfolio return of longer period such as 12-month or 15-month, I focus on three-month period following a fiscal year-end because the effects of the 10-K filing would be mostly shown during this period. During this period, firms file their $10-\mathrm{K}$ with the SEC and thus most of information about current fiscal year's annual earnings will be released to investors.

Cumulative return for each month of a three-month window is expressed as a percentage of the three-month total portfolio return. That is, the percentage of each month is computed as cumulative monthly return divided by three-month total cumulative returns. Thus, such percentage at the end of the third month is 1 . The timeliness metric measures how quickly earnings-based price is formed during a specific period, independent of the overall explanatory power of earnings for returns (Butler et al., 2007). 
The computed data points are plotted in the graph over the three-month period. The plotted percentage for each month $\mathrm{i}$ is:

$$
y_{i}=\text { Cumulative monthly return } i / \text { Total return }
$$

The timeliness of annual earnings is represented by the estimated area under the curve for a given portfolio. The area represents the speed at which hedge portfolio return is earned over the three-month period since the plotted percentage of each month is computed as cumulative monthly return divided by three-month total cumulative returns. The graph is plotted over the three-month period after outliers (top 2\% and bottom $2 \%$ in ratios) are eliminated (Note 5). Since ratios are assumed to lie between 0 and 1, outliers are deleted so that the effect of extreme ratios can be minimized.

Finally, I compare earnings timeliness between pre-acceleration period and post-acceleration period to examine whether there is any effect of the shortened deadline on earnings timeliness. Timeliness is represented by the estimated area under the curve for a given portfolio. Accordingly, larger area implies that annual earnings information is reflected in stock market at a faster rate compared to smaller area. The size under the curve is equal to (Butler et al., 2007; Cuijpers et al., 2010):

$$
A R E A=0.5 \sum_{m=1}^{2} \frac{B H m-1+B H m}{B H 12}=0.5+\sum_{m=1}^{2}(B H m / B H 12)
$$

where $\mathrm{BH}_{\mathrm{m}}$ is the firm's buy-and-hold return from month 1 through $\mathrm{m}$. Following Rahman, Tay, Ong, and Cai(2007), I use independent samples t-test to compare areas under the graphs between pre-acceleration period and post-acceleration period.

\section{Sample and Descriptive Statistics}

I focus on firms that are subject to the acceleration rule (i.e. "small accelerated filers" and "large accelerated filers"). I identify small accelerated filers as domestic firms with market capitalization between $\$ 75$ million and $\$ 700$ million at the end of fiscal year of 2002. Large accelerated filers are identified as those with market capitalization of $\$ 700$ million or more at the end of fiscal year of 2002. From the list of potential accelerated filers, I exclude firms that do not have certain information such as EPS, share price, and monthly return during my sample period of 1999-2008 in order to prevent changes in sample composition over time. I exclude these firms since changes in sample composition may influence results. Such information is available from Compustat and CRSP. After elimination, small accelerator sample and large accelerator sample include 705 firms and 614 firms, respectively. Control sample contains 717 firms that are exempt from the rule. All sample firms have December 31 fiscal year-end.

For accelerator sample, the $25^{\text {th }}$ percentile and $75^{\text {th }}$ percentile of January ratio are -0.05 and 0.82 , respectively, with the median of 0.37 . The $25^{\text {th }}$ percentile and $75^{\text {th }}$ percentile of February ratio are 0.28 and 1.09 , respectively, with the median of 0.70 .

\section{Results}

Figure 1 and Figure 2 display the monthly returns as a percentage of the three-month total returns of hedge portfolio formed from small accelerators and non-accelerators, respectively. Monthly hedge portfolio buy-and-hold returns are cumulated during a three-month period after the fiscal-year end. In Figure 1, the area under the graph for post-acceleration period is close to that for pre-acceleration period. Based on independent samples t-test, the difference in the areas is not statistically significant (Table 2). Therefore, I cannot reject the null hypothesis of no difference in timeliness between pre-acceleration and post-acceleration. In Figure 2, there is no significant difference in the pre- and post-acceleration period areas for control sample.

Figure 3 and Figure 4 display cumulative monthly return timeliness of large accelerators and non-accelerators, respectively. In Figure 3, the two lines, which represent the returns of pre- and post-75 day acceleration period, are close to each other, suggesting that timeliness has not changed after the large accelerators were required to shorten their 10-K filing deadline to 75 days from 90 days. Furthermore, the difference in two areas for pre- and post-60 day acceleration period is not statistically significant (Table 2). In addition, timeliness graphs for control sample in Figure 4 do not display significant differences in areas over the sample period of 1999-2008.

In sum, it appears that the acceleration rule did not have a significant impact on how fast earnings information is impounded into stock market for both small and large accelerators. Given that mean 10-K filing lag has significantly decreased in the post-acceleration period (Krishann \& Yang, 2009; Doyle et al., 2010), it seems unexpected that the shortened filing deadline has little effect on earning timeliness. One possible explanation for this finding can be found in the increase in earnings announcement lags (the number of days between fiscal 
year-end and earnings announcement date) over the recent years.

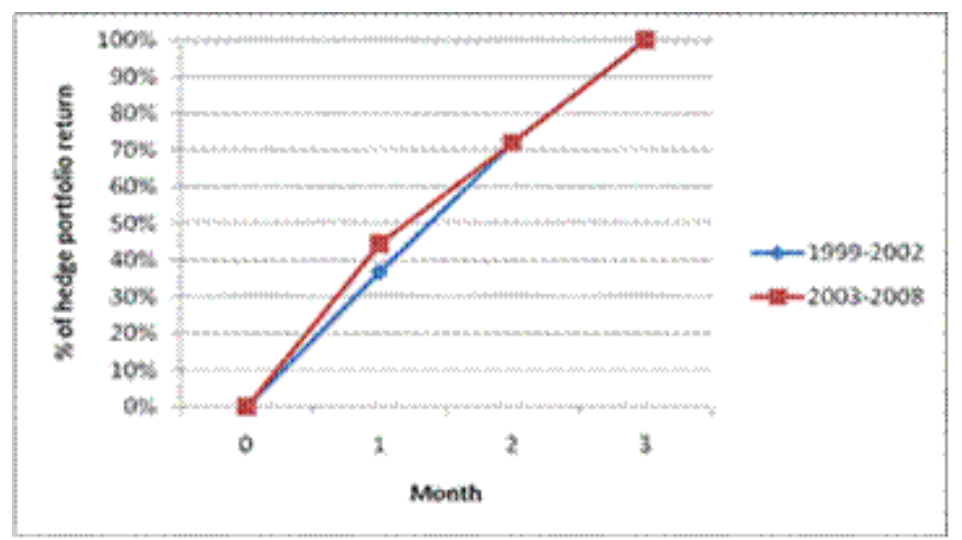

Figure 1. Cumulative monthly return timeliness of small accelerators

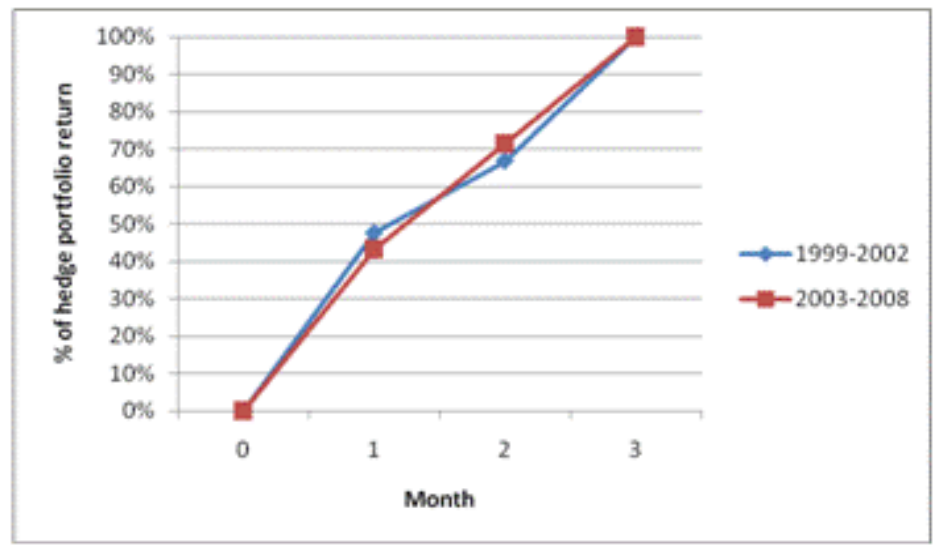

Figure 2. Cumulative monthly return timeliness of non-accelerators

Table 2. Changes in earnings timeliness

\begin{tabular}{|c|c|c|c|c|c|c|}
\hline \multicolumn{7}{|c|}{ Panel A: Small Accelerator } \\
\hline & \multicolumn{3}{|c|}{ Accelerator Sample } & \multicolumn{3}{|c|}{ Control Sample } \\
\hline Fiscal Year & 1999-2002 & 2003-2008 & Difference & 1999-2002 & 2003-2008 & Difference \\
\hline Area under the curve & 1.59 & 1.67 & 0.08 & 1.64 & 1.65 & 0.01 \\
\hline \multicolumn{7}{|c|}{ Panel B: Large Accelerator } \\
\hline & \multicolumn{3}{|c|}{ Accelerator Sample } & \multicolumn{3}{|c|}{ Control Sample } \\
\hline Fiscal Year & 1999-2002 & 2003-2005 & Difference & 1999-2002 & 2003-2005 & Difference \\
\hline Area under the curve & 1.51 & 1.63 & 0.12 & 1.64 & 1.54 & -0.10 \\
\hline Fiscal Year & 2003-2005 & $2006-2008$ & Difference & 2003-2005 & 2006-2008 & Difference \\
\hline Area under the curve & 1.63 & 1.71 & 0.08 & 1.54 & 1.74 & 0.20 \\
\hline
\end{tabular}

Although firms filed their 10-K sooner to meet the new shortened deadlines, it took longer for them to release their earnings announcement, which can be unintended outcome of the accelerated deadline. The new tightened deadlines of 10-K filing imposed time pressure on many accelerators and their audit firms (Lambert et al., 2014). Thus, it is possible that firms' efforts to meet the new deadlines lead to delayed earnings announcement, which, in turn, can affect the earnings timeliness of $10-\mathrm{K}$.

Table 3 presents trends in fourth quarter earnings announcement lag (the number of days between the quarter-end and the earnings announcement date) for my sample period. I present only fourth quarter earnings announcement 
lag since fourth quarter earnings announcement date is close to $10-\mathrm{K}$ date. Consistent with prior studies (Smith, 2007; Krishnan \& Yang, 2009), mean earnings announcement lag (EAL) for both small and large accelerators display an overall increase from 1999 to 2008. Mean EAL of small accelerators increased from 46 days in 1999 to 52 days in 2008. Mean EAL prior to the accelerated $10-\mathrm{K}$ deadline is 45 days while it is 51 days following the new 75-day deadline. The large difference of 6 days in mean EAL suggests that the accelerated 10-K deadline may have affected firms' decision regarding when to release their earnings press release. Large accelerators also faced an increase in mean EAL from 33 days in 1999 to 38 days in 2008. Mean EALs for 1999-2002, 2003-2005, and 2006-2008 are 33, 37, and 38 days, respectively.

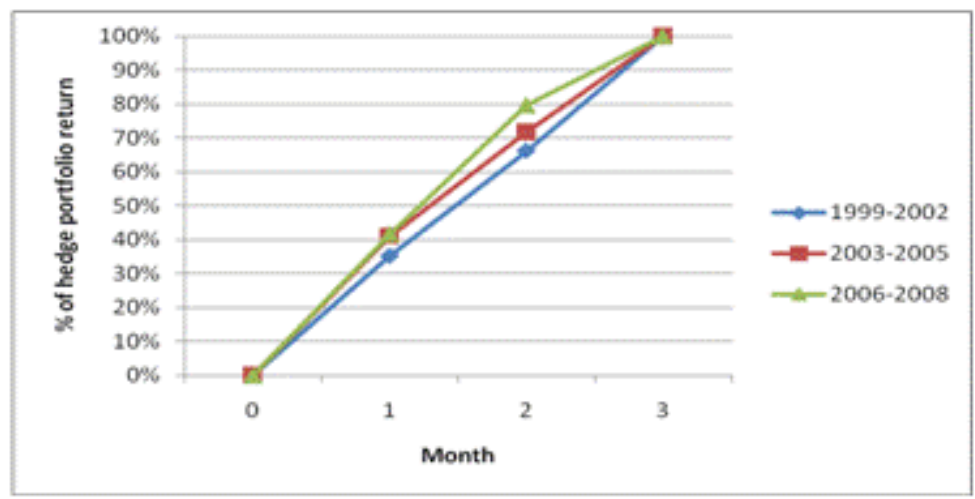

Figure 3. Cumulative monthly return timeliness of large accelerators

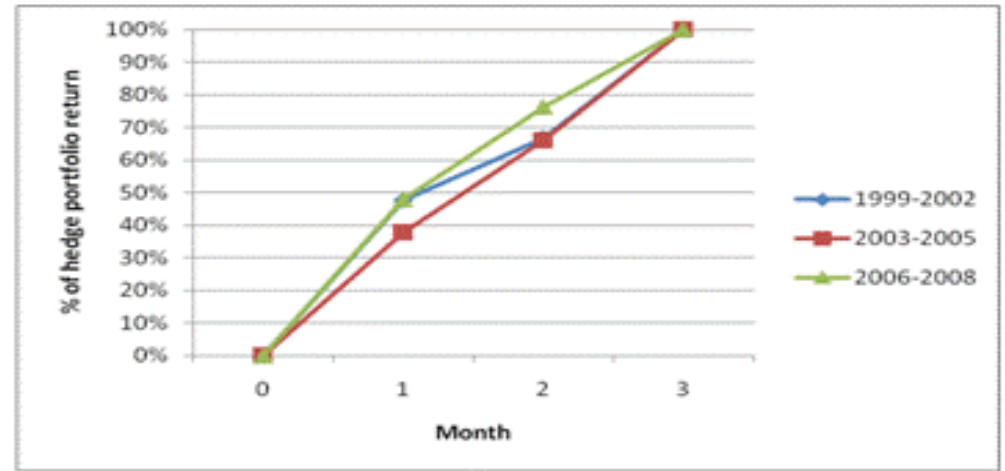

Figure 4. Cumulative monthly return timeliness of non-accelerators

By finding no significant benefits of the acceleration rule, the study provides some evidence that the SEC's intention to increase market efficiency by forcing firms to file periodic reports earlier might be hard to be fully accomplished. This suggestion is in line with other studies that document the costs of the acceleration rule. For example, Bryant-Kutcher et al. (2013) document the reduced reliability of the financial reports, which is the possible cost of accelerating filing deadlines of accounting reports. Lambert et al. (2014) provide support for claims made by auditors that the accelerations of $10-\mathrm{K}$ filings have the capacity to reduce the quality of financial information.

\section{Conclusion}

In this paper, I examine some of the possible consequences of the SEC's decision to accelerate 10-K filing dates. In implementing the rule, the SEC claimed that the legislation would improve the timeliness or relevance of periodic reports. On the other hand, some auditors and preparers argued that the accelerated deadlines may decrease the reliability or accuracy of reports since auditors have less time to audit financial statements. Another drawback is possible increase in costs firms might have to incur to accelerate their 10-K filing. This paper attempts to examine whether the acceleration had any impact on the earnings timeliness, the speed at which annual earnings information gets impounded into stock prices.

In order to measure earnings timeliness, I first construct a perfect foresight hedge portfolio from small 
accelerators and large accelerators, including a long position in firms in highest scaled earnings changes and short position in firms in lowest scaled earnings changes. Second, I calculate hedge portfolio returns at the end of each month of a three-month period following the fiscal year end. Each of monthly returns is expressed as a percentage of the three-month total portfolio return. The cumulative difference between such percentages of pre-acceleration period and post-acceleration period is a measure of the difference in earnings timeliness. One limitation of the study is that the timeliness measure has a limitation in examining timing within each month because it examines only monthly return at the end of the first and second months.

In conclusion, the research findings provide evidence as to the impact of the new acceleration rule. It appears that the accelerated 10-K filing deadline has no significant effect on earnings timeliness for both small and large accelerators possibly because of concurrent increase in earnings announcement lag. Overall, my results provide little support for the SEC's claim that the accelerated deadline would improve timeliness of periodic reports. Thus, one implication of my findings is that forcing firms to file periodic reports earlier might not achieve the motivation for accelerating filing deadlines. Future research can examine the possible effect of the acceleration rule on financial reporting quality such as accounting conservatism and earnings management.

Table 3. Trends in earnings announcement lag (\# of days from fiscal year-end to earnings announcement date)

\begin{tabular}{|c|c|c|c|c|c|c|c|c|c|c|}
\hline \multicolumn{11}{|c|}{ Panel A: Trends in Earnings Announcement Lag of Small Accelerators } \\
\hline Fiscal Year & $\underline{1999}$ & $\underline{2000}$ & $\underline{2001}$ & $\underline{2002}$ & $\underline{2003}$ & $\underline{2004}$ & $\underline{2005}$ & $\underline{2006}$ & $\underline{2007}$ & $\underline{2008}$ \\
\hline Mean & 46 & 44 & 43 & 46 & 45 & 50 & 51 & 54 & 51 & 52 \\
\hline First Quartile & 27 & 25 & 28 & 29 & 29 & 32 & 31 & 31 & 31 & 35 \\
\hline Median & 40 & 39 & 38 & 42 & 42 & 47 & 47 & 51 & 51 & 50 \\
\hline Third Quartile & 55 & 54 & 52 & 56 & 56 & 62 & 60 & 60 & 60 & 63 \\
\hline \multicolumn{11}{|c|}{ Panel B: Trends in Earnings Announcement Lag of Large Accelerators } \\
\hline Fiscal Year & $\underline{1999}$ & $\underline{2000}$ & $\underline{2001}$ & $\underline{2002}$ & $\underline{2003}$ & $\underline{2004}$ & $\underline{2005}$ & $\underline{2006}$ & $\underline{2007}$ & $\underline{2008}$ \\
\hline Mean & 33 & 32 & 32 & 33 & 35 & 38 & 38 & $\overline{38}$ & $\overline{38}$ & 38 \\
\hline First Quartile & 24 & 23 & 23 & 23 & 26 & 26 & 25 & 25 & 26 & 28 \\
\hline Median & 27 & 29 & 29 & 30 & 29 & 32 & 32 & 32 & 35 & 35 \\
\hline Third Quartile & 40 & 39 & 38 & 41 & 41 & 41 & 45 & 45 & 44 & 47 \\
\hline
\end{tabular}

\section{Acknowledgments}

The author would like to thank Christopher Jones and Sok-Hyon Kang for their advice and comments. The author also thanks workshop participants at The George Washington University and the 2015 American Accounting Association Mid-Atlantic Region Meeting.

\section{References}

Alford, A., Jones, J., Leftwich, R., \& Zmijewski, M. (1993). The relative informativeness of accounting disclosures in different countries. Journal of Accounting Research, 183-223. http://dx.doi.org/10.2307/2491170

Atiase, R. K., Bamber, L. S., \& Tse, S. (1989). Timeliness of financial reporting, the firm size effect, and stock price reactions to annual earnings announcements. Contemporary Accounting Research, 5(2), 526-552. http://dx.doi.org/10.1111/j.1911-3846.1989.tb00722.x

Bryant-Kutcher, L., Peng, E. Y., \& Weber, D. P. (2013). Regulating the timing of disclosure: Insights from the acceleration of 10-K filing deadlines. Journal of Accounting and Public Policy, 32(6), 475-494. http://dx.doi.org/10.1016/j.jaccpubpol.2013.08.003

Bryant-Kutcher, L., Peng, E. Y., \& Zvinakis, K. (2007). The impact of the accelerated filing deadline on timeliness of 10-K filings. http://dx.doi.org/10.2139/ssrn.735583

Bushman, R., Chen, Q., Engel, E., \& Smith, A. (2004). Financial accounting information, organizational complexity and corporate governance systems. Journal of Accounting and Economics, 37(2), 167-201. http://dx.doi.org/10.1016/j.jacceco.2003.09.005

Butler, M., Kraft, A., \& Weiss, I. S. (2007). The effect of reporting frequency on the timeliness of earnings: The cases of voluntary and mandatory interim reports. Journal of Accounting and Economics, 43(2), 181-217. http://dx.doi.org/10.1016/j.jacceco.2007.02.001 
Chambers, A. E., \& Penman, S. H. (1984). Timeliness of reporting and the stock price reaction to earnings announcements. Journal of Accounting Research, 21-47. http://dx.doi.org/10.2307/2490700

Choudhary, P., Merkley, K. J., \& Schloetzer, J. D. (2014). Disclosure timing and the economic role of mandatory reporting: Evidence from managers'decisions to file audited reports early. Available at SSRN 1436538.

Cuijpers, R., \& Peek, E. (2010). Reporting frequency, information precision and private information acquisition. $\begin{array}{lllll}\text { Journal of Business } \quad \text { Finance } \quad \text { A } & \text { Accounting, } & 37(1-2), & \end{array}$ http://dx.doi.org/10.1111/j.1468-5957.2009.02180.x

DeFond, M., Hung, M., \& Trezevant, R. (2007). Investor protection and the information content of annual earnings announcements: International evidence. Journal of Accounting and Economics, 43(1), 37-67. http://dx.doi.org/doi:10.1016/j.jacceco.2006.09.001

Doyle, J. T., \& Magilke, M. J. (2013). Decision usefulness and accelerated filing deadlines. Journal of Accounting Research, 51(3), 549-581. http://dx.doi.org/10.1111/joar.12004

Financial Accounting Standards Board (FASB). (2010). Statement of Financial Accounting Concepts No. 8 Conceptual Framework for Financial Reporting. Retrieved from http://www.fasb.org/cs/ContentServer?site=FASB\&c=FASBContent_C\&pagename=FASB\%2FFASBConte nt_C\%2FProjectUpdatePage\&cid=900000011079

Givoly, D., \& Palmon, D. (1982). Timeliness of annual earnings announcements: Some empirical evidence. Accounting Review, 486-508.

Impink, J., Lubberink, M., Van Praag, B., \& Veenman, D. (2012). Did accelerated filing requirements and SOX Section 404 affect the timeliness of 10-K filings? Review of Accounting Studies, 17(2), 227-253. http://dx.doi.org/10.1007/s11142-011-9172-5

Krishnan, J., \& Yang, J. S. (2009). Recent trends in audit report and earnings announcement lags. Accounting Horizons, 23(3), 265-288. http://dx.doi.org/10.2308/acch.2009.23.3.265

Lambert, T. A., Jones, K. L., \& Brazel, J. F. (2014). Audit Time Pressure and Earnings Quality: An Examination of Accelerated Filings. Available at SSRN 963402.

Li, E., \& Ramesh, K. (2009). Market reaction surrounding the filing of period SEC reports. The Accounting Review, 84, 1171-1208. http://dx.doi.org/10.2308/accr.2009.84.4.1171

Lys, T., \& Sabino, J. S. (1992). Research design issues in grouping-based tests. Journal of Financial Economics, 32(3), 355-387. http://dx.doi.org/10.1016/0304-405X(92)90033-T

Rahman, A. R., Tay, T. M., Ong, B. T., \& Cai, S. (2007). Quarterly reporting in a voluntary disclosure environment: Its benefits, drawbacks and determinants. The International Journal of Accounting, 42(4), 416-442. http://dx.doi.org/10.1016/j.intacc.2007.09.006

Securities and Exchange Commission (SEC). (2002). Release No. 33-8128, Acceleration of periodic report filing dates and disclosure concerning website access to reports.

Securities and Exchange Commission (SEC). (2005). Release No. 33-8644, Revision to accelerated deadlines for filing periodic reports.

Sengupta, P. (2004). Disclosure timing: Determinants of quartely earnings release dates. Journal of Accounting and Public Policy, 23, 457-482. http://dx.doi.org/10.1016/j.jaccpubpol.2004.10.001

Smith, M. J. (2008, September). Evidence of a recent increase in the usefulness of quarterly earnings announcements. AAA.

\section{Notes}

Note 1. SEC Final Rule 33-8128 [September 5, 2002].

Note 2. SEC Final Rule 33-8644 [December 21, 2005].

Note 3. Statement of Financial Accounting Concept No. 2 [1980]

Note 4. SEC Final Rule 33-8644 [December 21, 2005].

Note 5 . Deleting top $1 \%$ and bottom $1 \%$ in ratios as outliers produces similar results. 


\section{Copyrights}

Copyright for this article is retained by the author(s), with first publication rights granted to the journal.

This is an open-access article distributed under the terms and conditions of the Creative Commons Attribution license (http://creativecommons.org/licenses/by/3.0/). 